O. Shefer ${ }^{1}$, N. Ichanska ${ }^{2}$, B. Topikha ${ }^{1}$, V. Shefer ${ }^{1}$

${ }^{1}$ Poltava National Technical Yuri Kondratyuk University, Poltava, Ukraine

${ }^{2}$ Taras Shevchenko National University of Kyiv, Kyiv, Ukraine

\title{
THE WAYS OF TECHNICAL REALIZATION OF ADAPTIVE ALGORITHM OF COMPENSATION OF NON-LINEAR DISTORTIONS OF RADIO DEVICES
}

\begin{abstract}
The practical realization of potential opportunities of onboard radio local systems of radio local systems (OBRLS) that are currently considerably higher than their real approachable technical characteristics is one of the main tasks of modern theory and practice of electronic and telecommunication. The authors of the article proposed some specific technical offers and ways of physical realization of scientifically grounded algorithm of adaptive compensation of non linear distortions (ACNLD). The insertion of artificial main and supportive entrances into the scheme of non-linear adaptive compensators allowed using the general theory of adaptive systems for their synthesis. The practical usage of synthesized following such a principle ACNLD according to the created recommendations allows to significantly increase the indices of quality of OBRLS in the real conditions of their functioning, comparing with the already known ones. An additional advantage of proposed adaptive method of expansion of linear dynamic diapason (LDD) is an improvement of all-weather of OBRLS and increasing of probability of identification of radio local maps of locality captured in different weather conditions without any additional changeovers. Except for this, a flexible reserve for the noise immunity of OBRLS is being fulfilled that allows taking into consideration the possible improvements of means of radio electronic struggle. Synthesized ACNLD are considerably free from many drawbacks of linear determined means of expansion of dynamic diapason of radio receiving devices (RRD) and also they have simpler apparatus realization. Except, in a process of projection of ACNLD a considerably less volume of a priori information about the parameters of LDD is needed for the calculation of already known schemes of depression of non-linear distortions. The transferring functions of adaptive filters of ACNLD are quite quickly gather at the non-linear transferring function of radio device (RD) provided that an effective convergence can be seen only with the presence of the inner noises at least unless they exceed the non-linear distortions by the level.
\end{abstract}

Keywords: radio device, adaptive compensator, non-linear distortion, internal noises, amplitude characteristic, dynamic diapason.

\section{Introduction}

The opportunities of practical realization of OBRLS are considerably limited by an amount of internal (relatively low apparatus reliability and nonstability of parameters, limitedness of dynamic diapason of radio receiving devices of OBRLS) and external (unsteadiness of conditions of expansion of radio waves in time, falling of obstacles on the entrance of RRD). This, first of all, explains currently noticeable lagging of the real indices of quality of functioning of OBRLS from their potential opportunities.

The weightier factor that significantly influences on the quality of functioning of OBRLSs and their noise-immunity in conditions of radio electronic struggle is the limitedness of dynamic diapason of the real RRDs as a consequence of the non-linearity of their amplitude characteristics (AC).

The known linear adaptive compensators of nonlinear distortions can be characterized by the presence of the main and the supportive entrances. The mixture of beneficial signal and obstacle [1-3] is correspondingly comes to these entrances.

Herewith, the obstacle in the supportive entrance is correlated only the signal of the obstacle from the main entrance and is statistically not connected (or less correlated) with the beneficial signal [1].

To have the possibility to directly use the mathematic apparatus of theory of adaptive systems [1, $4,5]$ and with the purpose of formalization of the task of adaptive compensation of non-linear distortions imagine the exit and the entrance of monodimensional radio devices (RD) as the main the supportive entrances of non-linear adaptive compensator, correspondingly. The mentioned entrances will be further called adaptive compensators of non-linear distortions (ACNLD) [1, 6].

The purpose of the article: is the development of scientifically grounded device of adaptive compensation of nonlinear distortions.

\section{The main part}

For any RRD (for which the type of the signal and the method of receiving are determined) the acceptable possibility of the error of $P_{0}$ determines the precise meaning of the necessary ratio signal/noise $h_{e f}$. In the process of coordinated filtration, the mentioned necessary meaning $h_{e f}$ is directly connected with the force of receiving signal $S$ and the spectral density of the noise $N_{0}$ by the expression: $h_{e f}=S T / N_{0}$ according to [7] $V_{u}=\frac{1}{T}=\frac{S}{N_{0} h}$. In the radio technical systems with the low level of signal, when $S / N_{0} F<<1$, the relation of the real velocity of transmission of information to the theoretical passing ability of the channel. It looks like:

$$
\eta_{e f}=\frac{V_{u}}{C_{\infty}} \equiv \frac{1}{h} \log _{2} e \approx \frac{0,963}{h} .
$$

So, if, for instance, in the binary system of a relative phase-subtracting modulation for ensuring the probability of the error $P_{0}=5 \cdot 10^{-4}$ it is needed to have $h=6,93(8,4 \mathrm{~dB})$, then the effectiveness of such a OBRLS will be equal to $10 \%$ for the velocity of receiving-transferring. According to the fact that 
during the approaching of velocity of receivingtransferring to the theoretical passing ability of channel of improvement of the connection system gives even less effect (maximally possible improvement don't exceed $10 \mathrm{~dB}$, like it was mentioned in the researches [7]), received OBRLS with velocity should considered to be relatively high and it can be beforehand predicted that the further increasing of effectiveness of the real radio technical systems that are working for the channels with additive Gaussian noise will face considerable difficulties.

The researches of possibilities of physical realization and the checking of ACNLD's capacity to work. With the purpose of increasing of significance of experimental researches for the task of improving of the indices of quality of OBRLS, this experiment will be better carried out on the example of expansion of the linear dynamic diapason of the narrow-band magnifier, since RDs of such a type make the main contribution into non-linear distortions in radio receiving devices (RRD) of OBRLS [6, 7]. Taking into consideration that dynamic diapason of the narrow-band magnifiers is limited on the whole by non-linear distortions of the third row [4], the choice of mentioned RD allows simplifying the structure of ACNLD (when $l=3$ ) and receiving the results of experimental researches that will have the exact physical treating and exact practical significance.

Having took into consideration the mentioned more precise definitions, a development of ACNLD of the third row was carried out. A coefficient of transferring of the narrow-band magnifier that was constructed on the basis of the micro scheme TL071 is equal to 10 (on the central frequency of the passing strip $-100 \mathrm{kHz}$ ) [8]. Multipliers were built on the integral micro schemes MC1496 [8]. The necessity of using of auto compensation of the constant component constructed on the basis of an integral micro scheme LM118, is conditioned by the presence in the outgoing signal of the micro scheme MC1496 a considerable (up to $5 \mathrm{~V}$ ) constant component that can break the normal work of the next cascades [8]. Besides, for the improvement of conditions of coordination of cascades to the exit of micro schemes LM1 18 connected emitting repeaters that are constructed on the transistors NTE101 [8]. A magnifier of the circle of reverse connection ACNLD, integrator and counter (a device of subtraction) are built with the help of micro schemes LM118 of emitted repeaters collected on the basis of transistors NTE101 [8].

Taking into consideration Given the need to measure the dynamic range of the narrowband amplifier, it is advisable to use the standard methodic to experimentally determine the dynamic range of electronic amplifiers with a decrease in sensitivity [9]. This methodic is based on measuring the amplitude characteristics of the amplifier. At the same time, the upper limit of its dynamic diapason is considered to be the value of the input (output) signal, which corresponds to the point of the graph of the amplitude characteristic of the amplifier, which defines on the axis of the ordinate from the ideal linear input-output dependence at a distance that corresponds to the sensitivity of the measuring RD [8].

For the metrological support of this measurement methodic, it is necessary to use an input signals' generator and an output voltage meter, in the process of measurement it is also recommended to control the shape of the output signal and its spectral characteristics $[1,10]$.

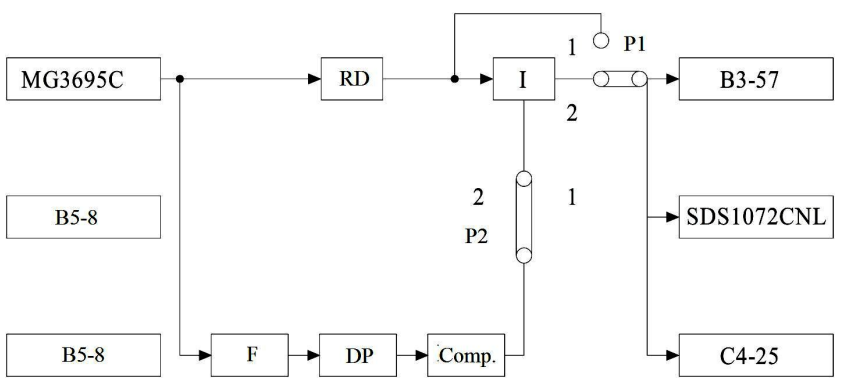

Fig. 1. Functional scheme of experimental installation

According to this, a set of measuring instruments with the technical characteristics of developed ACNLD model is needed to carry out this experiment. A set must include: the high-frequency signal generator MG3695C; microvoltmeter B3-57; oscilloscope SDS1072CNL and spectrum analyzer C4-25. Following that the MC1496 and LM1 18 micro schemes require a constant voltage of $\pm 9 \mathrm{~V}$ and for TL071 micro schemes $\pm 9 \mathrm{~V}$ it is advisable to use two power sources B5-8.

Based on the above clarifications, an experimental installation was developed, the functional scheme of which is presented in Fig. 1 [6]. During the checking the performance of the ACNLD model, the switch P1 was set to position 2, and the switch P2 was moved from position 1 to position 2 and back. To provide a visual representation of the effect of inhibition of nonlinear distortions using ACNLD, as RD, at this stage of the program's implementation of the experiment, a transistor frequency multiplier on 3, constructed on transistors NTE101, was used. In this case, the frequency of the input monochromatic signal was 100 $\mathrm{kHz}$, and its amplitude was $0.5 \mathrm{~V}$. The spectrographs of the signal at the output of the subtracting device when (P2-2) is disconnected and (P2-1) connected to the ACNLD taken from the screen of the spectrum analyzer C4-25. Here, the first harmonic of the output signal of the frequency multiplier for the convenience of observation is combined with the beginning of the reference. The obtained experimental results can be physically interpreted as the suppression of large nonlinear distortions on the background of a weak useful signal without distorting it. Following this, the first, second, fourth, fifth, etc. harmonics of the output signal of the frequency multiplier can be considered as a useful signal [11]. The comparison of spectrographs also confirms the theoretical conclusions that the potential accuracy of inhibition of nonlinear distortions of the third order is limited by nonlinear distortions of higher (first of all - fifth) orders.

To study the effect of the internal noise of the ACNLD model on the quality of its operation, the switches P1 and P2 were locked in position 2. As the 
RP, a narrowband amplifier was used [8]. It should be noted that the output voltage of the generator MG3695C was set at the level of sensitivity of the narrowband amplifier $(\sim 1 \mu \mathrm{V})$ at a frequency of $100 \mathrm{kHz}$. In order to increase the accuracy and reliability of the results at this stage of the program implementation of the experiment a low-noise adder, constructed on the TL071 micro scheme was used as a subtraction device. This adder has a level of internal noise $\approx(0.6-0.8) \mu \mathrm{V}$ in the frequency band (2.0-2.5) kHz, which is more than $20 \mathrm{~dB}$ lower than the amplitude of the minimum output signal of the amplifier equal to (8-10) $\mu \mathrm{V}$ in the same band of frequencies relative to the central frequency of $100 \mathrm{kHz}$ [8]. With the help of microvoltmeter B3-57, the signal voltage was measured at the output of the ACNLD model. It was about $10 \mu \mathrm{V}$.

Then the switch P1 was transferred from position 2 to position 1, the 2nd position of the switch P2. Having convinced by the indicators of the device B3-57 that the internal noise of the subtraction device did not practically affect the output of the narrowband amplifier, the switch P1 was locked into position 2, and the switch P2 moved from the 2 nd position to the 1 st. In this case, the voltage of the output signal, controlled by the microvoltmeter B357, did not change and was $10 \mu \mathrm{V}$.

Results of measurements of AC of the narrowband amplifier, performed according to the standard method of experimental determination of the dynamic range of the amplifier to reduce their sensitivity [3, 6, 7], are presented in Fig. 2.

To measure the dynamic range of the narrowband amplifier, the switch P1 was set to the 1st position. In this case, the width of the linear dynamic range of this narrowband amplifier was $63.5 \mathrm{~dB}$.

In the process of measuring the dynamic range of the ACNLD layout, the switch P1 was transferred to the 2nd position with the 1 st position of the switch P2. In this case, the width of the linear dynamic range of the ACNLD layout was $100.75 \mathrm{~dB}$.

\section{Conclusions}

The analysis of data received as a result of carrying out described experimental researches allows making the following conclusions:

ACNLD have an exact practical realization on the approachable radio cell basis and are capable to work.

Getting out of action (shutdown) of adaptive filter doesn't lead to reduction of reliability (refusal) ACNLD comparing with the reliability of RD (narrow-band magnifier).

Internal noises ACNLD $(\mathrm{Na} \approx 40 \mu \mathrm{V})$ don't worsen operational characteristics of signals on the exit of ACNLD comparing with the noise characteristics of output signal of RD (narrow-band magnifier $\mathrm{N} \approx 8 \mu \mathrm{V})$.

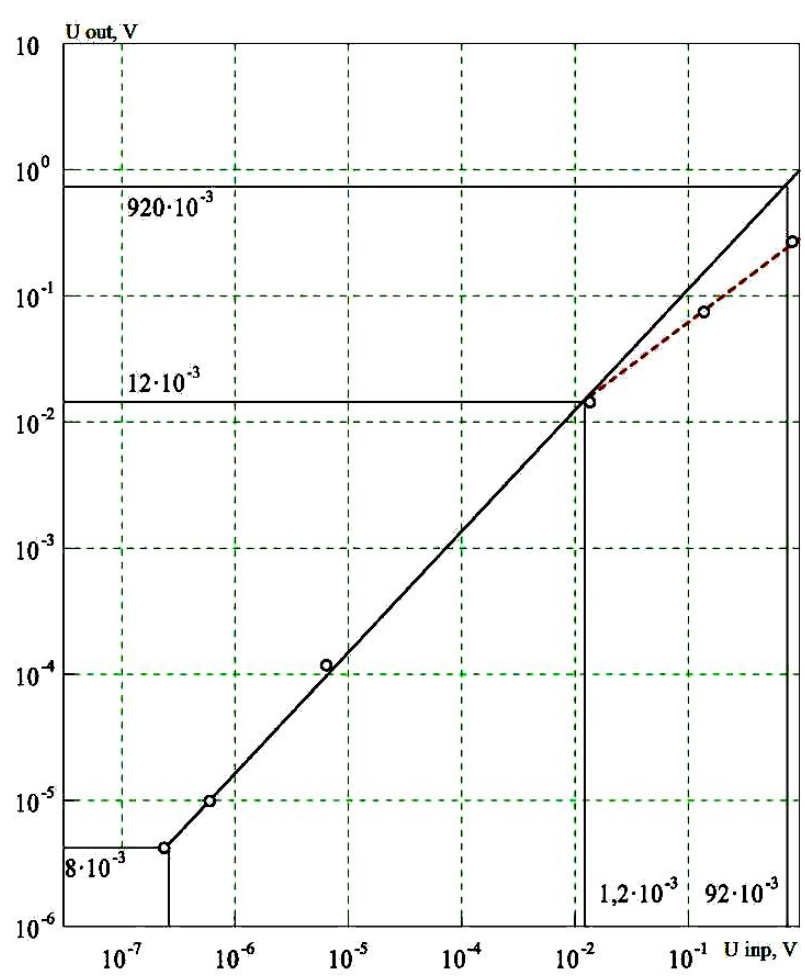

Fig. 2/ Measured AC of the narrow-band RD with the compensator of obstacles with the $3^{\text {rd }}$ order: solid line $-\mathrm{AC}$ of the narrow-band RD with the compensator; dotted line - AC of the narrow-band RD with the unplugged compensator;

(measured meanings are marked with the circles)

The use of the ACNLD of the third row allowed to increase the upper limit of the linear dynamic range by reducing the sensitivity of the narrowband amplifier $(\Delta f=2,5 \mathrm{kHz})$ to the harmonic input signal $(f 0=100$ $\mathrm{kHz}$ ) with $1.2 \mathrm{mV}$ - at the input (12 $\mathrm{mV}$ - on the output) to $92 \mathrm{mV}$ - at the input (920 mV - output), which corresponds to the expansion of its linear dynamic range from $63.5 \mathrm{~dB}$ to $100.75 \mathrm{~dB}$, ie $37.25 \mathrm{~dB}$. The incomplete gain (the theoretically expected result is 60$67 \mathrm{~dB}$ ) can be explained by the inappropriate use of the dynamic range of the actual ACNLD (first of all its multiplier MC1496, the dynamic range of which in some cases reaches $70 \mathrm{~dB}$ ).

Indeed, the required level of internal noise ACNLD in accordance with the expression (3.44) should be 1-1.2 $\mathrm{mV}$, and in reality it has an order of $40 \mathrm{mV}$. Therefore, the upper limit of the dynamic range of the ACNLD was insufficient, which led to the incomplete practical implementation of the potential capabilities of the developed ACNLD layout.

The most important conclusions of the theoretical analysis of the accuracy and dynamic characteristics of the ACNLD and the main provisions of the scientifically based method of their designing have been experimentally confirmed.

\section{REFERENCES}

1. Radioelektronnyie sistemyi: osnovyi postroeniya i teoriya / Ed. by Ya. Shirmana. - Moscow: ZAO MAKVIS, 1998. - P. 828.

2. Polyak B. T., Tsyipkin Ya. Z. Robastnyie algoritmyi adaptatsii // Avtomatika i telemehanika. - 1980. - no 10. - P. 91-97.

3. Shefer O. V. The increase of radio technical noise immunity systems by adaptive premaligant and inversive correlation approach to the detection of the beneficial signal / O. V. Shefer // Scientific Notes UNDIZ. - K.: SUT, 2017, no. 1(45), pp. $82-88$. 
4. Gutkin L.S. Proektirovanie radiosistem i radioustroystv. - M.: Radio i svyaz, 1986. - P. 288.

5. Barsov V. I. Mathematic methods and technical means of ASU / V. I. Barsov, V. A. Krasnobayev, Z. V. Barsova. - Kh.: Tochka, 2012. $-301 \mathrm{c}$.

6. Shefer O. V. Synthesis of adaptive algorithm of compensation of nonlinear distortions of radio devices / O. V. Shefer. Systems of control, navigation and communication. - Poltava: Polt NTU, 2018. - №1 (47). - P. 64-68.

7. Buckingham M. Noises in electronic devices and systems: Translation from English. - M.: Myr, 1986. -399 pp.

8. Charles Platt. Encyclopedia of electronic components. Volume 3 / Charles Platt, Fredrick Yansson. - BHV-Petersburg, 2017. - 288 p.

9. Kozelkov S.V. Development of the antenna system guidance algorithm / S. V. Kozelkov, N. P. Rudenko, V. F. Stolbov, S. A. Tyshchuk // Information processing systems. National Academy of Sciences PAMM, HVU. - Kharkiv: CFC "Transport of Ukraine". - 2000. - Issue. 4(10). - Pp. 39-43.

10. Radio engineering: Encyclopedic educational handbook; educational manual. / edited by Y. L. Mazor, E. A. Machuskyi,

11. V. I. Pravda. - K.: H. school, 1999. - 838 p.

12. Konyakhin V. V.Micro schemes for the equipment of space assignment. Practical manual / V. V. Konyakhin and others. M.: Technosphere, 2017. -388 p.

Рецензент: д-р техн. наук, с.н.с. Є. В. Гаврилко, Державний університет телекомунікацій, Київ

Received 15.10.2018

Accepted for publication 21.11.2018

\title{
Шляхи технічної реалізація алгоритму адаптивної компенсації нелінійніх спотворень радіопристроїв
}

\author{
О. В. Шефер, Н. Г. Ічанська, Б. В. Топіха, В. О. Шефер
}

Практична реалізація потенційних можливостей бортових радіолокаційних систем (БРЛС), котрі на даний час суттєво вищі від реально досяжних їх технічних характеристик, є однією із головних задач сучасної теорії і практики електроніки та телекомунікацій. У статті авторами запропоновано конкретні технічні пропозиції та шляхи фізичної реалізації науковообгрунтованого алгоритму адаптивної компенсації нелінійних спотворень (АКНС). Введення штучних основного i опорного входів у схему нелінійних адаптивних компенсаторів дозволило застосувати для їх синтезу загальну теорію адаптивних систем. Практичне використання синтезованих, за таким принципом АКНС, у відповідності із розробленими рекомендаціями, дозволяє суттєво підвищити показники якості БРЛС у реальних умовах їх застосування, в порівнянні 3 відомими. Додатковою перевагою запропонованого адаптивного способу розширення лінійного динамічного діапазону радіоприймальних пристроїв (РПП) $є$ покращення всепогодності БРЛС i підвищення ймовірності ідентифікації радіолокаційних карт місцевості, знятих у різних умовах, без додаткових переналаштувань. Крім того, одночасно забезпечується гнучкий запас за перешкодостійкістю БРЛС, що дозволяє врахувати можливі удосконалення засобів радіоелектронної боротьби. Синтезовані АКНС в значній мірі вільні від багатьох недоліків лінійних детермінованих способів розширення динамічного діапазону РПП, а також мають більш просту апаратурну реалізацію. Крім того, в процесі проектуванні АКНС необхідний суттєво менший обсяг апріорної інформації про параметри РПП, для розрахунку відомих схем пригнічення нелінійних спотворень. Передавальні функції адаптивних фільтрів АКНС досить швидко сходяться до нелінійної передавальної функції радіопристрою (РП), причому ефективна збіжність спостерігається за наявності внутрішніх шумів принаймні до тих пір, поки вони не перевищують за рівнем компенсовані нелінійні спотворення

Ключов і слова: радіопристрій, адаптивна компенсація, нелінійні спотворення, внутрішні шуми, амплітудна характеристика, динамічний діапазон.

\section{Пути технической реализация адаптивного алгоритма компенсации нелинейных искажений радиоустройств}

\author{
А. В. Шефер, Н. Г. Ичанская, Б. В. Топиха, В. А. Шефер
}

Практическая реализация потенциальных возможностей бортовых радиолокационных систем (БРЛС), которые в настоящее время существенно выше реально достижимых их технических характеристик, является одной из главных задач современной теории и практики электроники и телекоммуникаций. Авторами в статье предложены конкретные технические предложения и пути физической реализации научно-обоснованного алгоритма адаптивной компенсации нелинейных искажений (АКНИ). Введение искусственных основного и опорного входов в схему нелинейных адаптивных компенсаторов позволило применить для их синтеза общую теорию адаптивных систем. Практическое использование синтезированных, по такому принципу АКНИ, в соответствии с разработанными рекомендациями, позволяет существенно повысить показатели качества БРЛС в реальных условиях их применения, по сравнению с известными. Дополнительным преимуществом предложенного адаптивного способа расширения линейного динамического диапазона радиоприемных устройств (РПУ) является улучшение всепогодности БРЛС и повышение вероятности идентификации радиолокационных карт местности, снятых в разных условиях, без дополнительной перенастройки. Кроме того, одновременно обеспечивается гибкий запас по помехоустойчивости БРЛС, что позволяет учесть возможные усовершенствования средств радиоэлектронной борьбы. Синтезированные АКНИ в значительной степени свободны от многих недостатков линейных детерминированных способов расширения динамического диапазона РПУ, а также имеют более простую аппаратурную реализацию. Кроме того, в процессе проектировании АКНИ необходим существенно меньший объем априорной информации о параметрах РПУ, для расчета известных схем подавления нелинейных искажений. Передаточные функции адаптивных фильтров АКНИ достаточно быстро сходятся к нелинейной передаточной функции радиоустройства (РУ), причем эффективная сходимость наблюдается при наличии внутренних шумов по крайней мере до тех пор, пока они не превышают по уровню компенсированные нелинейные искажения.

Ключевые слова: радиоустройство, адаптивная компенсация, нелинейное искажение, внутренние шумы, амплитудная характеристика, динамический диапазон. 